\title{
Improvement of Controlling in the Financial Management of Enterprises
}

\author{
Nataliya Mazur ${ }^{1}$, Larysa Khrystenko ${ }^{2}$, Janka Pásztorová ${ }^{3}$, Mykola Zos-Kior ${ }^{4}$, \\ Iryna Hnatenko ${ }^{5}$, Polina Puzyrova ${ }^{5}$, Viktoriia Rubezhanska ${ }^{6}$ \\ ${ }^{1}$ Kamianets-Podilskyi National Ivan Ohiienko University, Paniwetska str. 13a/11, 32313, \\ Kamianets-Podilskyi, Ukraine \\ ${ }^{2}$ Volodymyr Dahl East Ukrainian National University, Tsentralnyi Prospect. 59-a, 93400, \\ Severodonetsk, Ukraine \\ ${ }^{3}$ University of Economics in Bratislava, Dolnozemská cesta 1,852 35, Bratislava, Slovak Republic \\ ${ }^{4}$ Poltava State Agrarian University, Skovoroda str. 1/3, 36003, Poltava, Ukraine \\ ${ }^{5}$ Kyiv National University of Technologies and Design, Nemyrovycha-Danchenka str. 2, 01011, Kyiv, Ukraine \\ ${ }^{6}$ Luhansk Taras Shevchenko National University, Gogol str. 1, 92700, Starobilsk, Ukraine
}

\begin{abstract}
One of the components of a highly effective management system is operational controlling at the enterprise. At the same time, the most important indicator characterising the efficiency of the functioning of the enterprise and, accordingly, subject to controlling is its solvency, which affects the level of competitiveness of the enterprise and the efficiency of its adaptation to the changing conditions of the market environment. In this regard, the purpose of the research is to modernize the procedure of financial controlling based on the development of an integral model for determining and analysing the transformational solvency index. The article forms a universal model of financial condition assessment, in which all threshold values of the coefficients, calculated according to existing methods of financial stability assessment, are reduced to one scale and the accumulated impact of indicator values for previous periods of economic activity is taken into account.
\end{abstract}

DOI: 10.18421/TEM104-15

https://doi.org/10.18421/TEM104-15

Corresponding author: Viktoriia Rubezhanska,

Luhansk Taras Shevchenko National University, Starobilsk, Ukraine.

Email: rubezhiik@gmail.com

Received: 31 May 2021.

Revised: 19 September 2021.

Accepted: 25 September 2021.

Published: 26 November 2021.

(cc)BY-NC-ND (C) 2021 Nataliya Mazur et al; published by UIKTEN. This work is licensed under the Creative Commons Attribution-NonCommercial-NoDerivs 4.0 License.

The article is published with Open Access at www.temjournal.com
On the basis of the correlation analysis, the nature and strength of the dependence of the transformational solvency index on the factors influencing its formation and causing tendentious trends in the dynamics of its change during a certain period are determined.

Keywords - financial management, solvency, controlling, financial resources, financial condition, assessment, integral model, correlation analysis

\section{Introduction}

Trends of the modern market environment determine the significant role of entrepreneurship in the formation and development of innovative economies of any country in the world and, accordingly, ensuring its smooth transition to the sixth technological mode of innovative development of economic systems. At the same time, in conditions of fierce competition, limited resources and inaccuracy and distortion of information, the key to successful operation of enterprises is the presence of a system of high-quality management of organisational processes, which ensures their longterm development in the market. One of the components of this management system is controlling, which is a set of appropriate measures aimed at coordinating the optimal allocation and use of own and borrowed financial resources. Controlling contributes to the transformation of planned indicators by modifying them into final results, which must be achieved in a certain period of time, thus ensuring the optimal implementation of strategic goals and operational management decisions in appropriate activities [3], [8]. That is, with the help of controlling, financial coordination and interaction of planned and actual indicators of business activity in the context of full information support of management decisions are carried out. As a result of 
financial coordination and interaction of financial indicators, the main stakeholders form an idea of the real financial condition of the enterprise and the prospects for its further development. At the same time, one of the most important indicators that characterise the efficiency of the enterprise and, accordingly, subject to control is its solvency, which, in turn, affects the level of competitiveness of the entity and the effectiveness of its adaptation to changing market conditions. In this regard, the optimization of the process of assessing the solvency is an urgent task to increase the efficiency of controlling in the financial management of an enterprise.

\section{Literature Review}

The works of many scientists are devoted to the study of the specifics of using the concept of controlling in financial management of enterprises in various spheres of management. Thus, in the article by Wang, Wu, Ho, using the example of China, the influence of positive nature of the internal controlling system use on the value of bonds of the companies under study is determined [11]. Tou, Watanabe, Neittaanmäki considered ways to increase the financial performance of the American company Amazon through the use of controlling and organization of financing systems for technofinancial innovations [9]. In the research work of Pavlatos, the dependence of the level of financial indicators of novice travel companies on the use of the controlling concept in the management of available financial resources is investigated [7]. Vaio, Varriale, Trujillo formulated the importance of implementing a management and control system in the activities of Italian ports to ensure environmental sustainability and energy efficiency in the port sector as a whole [10]. Crespo, Rodrigues, Samagaio, Silva considered the role of internal factors (strategy, organizational structure and level of productivity of enterprises) in the implementation and adaptation of management and control systems in the initial stages of operation of companies [2]. Martin's scientific article is devoted to the study of changes over time in the elements of the controlling system in enterprise financial management [6]. The article by Lunt reflects the specific features of the implementation of financial controlling systems and different stages of the production process in industrial enterprises [5]. Alharbi, Jamil, Mahmood, Shaharoun considered the system of management controlling as a mediating factor between the influence of organizational culture on organizational innovation in organizations in Saudi Arabia [1]. In the scientific work by Korhonen, Laine, Martinsuo, a study of the perception degree of controlling over the management of uncertainties that accompany the process of making strategic decisions in doing business is carried out, and the need for close cooperation of managers in the formation of a program to control the use of financial resources in conditions of inaccurate information is determined [4].

Given the completeness and significance of the above scientific works, it is worth noting the need for further research in the direction of improving the process of organizing controlling in financial management at enterprises. In this regard, the purpose of the article is to modernize the procedure of financial controlling based on the development of an integral model for determining and analysing the transformational solvency index.

\section{Research Results and Discussion}

The effectiveness of entrepreneurship in any area of management is due to the influence of many rapidly changing environmental factors, characterized by the instability of their action. That is why the effectiveness of the management system at the enterprise is directly dependent on the availability of opportunities for rapid adaptation to change, as well as an effective methodology for determining the current financial condition with the establishment of bankruptcy risk based on operational controlling [12]. In this regard, controlling plays a significant role in the optimal allocation and use of own and borrowed financial resources in the process of enterprise functioning.

We believe that when forming a model for determining the level of financial stability of enterprises it is necessary to take into account the specific nature of changes, which reflects the accumulation over time of environmental impact, which can result in bankruptcy and rapid economic efficiency. The construction of this model is based on determining the magnitude of the deviation of the actual value of the solvency ratio from the threshold (crisis) one. To calculate the magnitude of these deviations, we consider it appropriate to use an integral model for estimating the transformational solvency index $\left(I_{t r}^{S o l}\right)$, which is to calculate the integral ratio based on determining the synergistic effect of certain economic indicators used in existing methods of assessing the financial condition of the enterprise. The use by managers of an integral model for determining the transformational solvency index will contribute to the effective determination of strategic goals of enterprise development and appropriate measures to achieve them based on rapid identification of risks of financial insolvency and early receipt of information necessary for management decisions. 
In the integral model of the transformational solvency index, we consider it necessary to ensure the accumulation of results of positive or negative impact of certain indicators of economic activity used in existing methods of assessing solvency, with their appropriate modernization. At the same time, it should be noted that the existing models for determining the level of solvency, developed in different countries of the world, reflect various specific characteristics of the functioning of enterprises in accordance with the specifics of a particular national economy. In this regard, to form a universal valuation model that would be suitable for use in any enterprise, regardless of their country of operation, it is necessary to bring all the threshold values of the coefficients to one scale, as well as take into account the synergistic effect of financial indicators for several periods of economic activity of the enterprise. As a result, the integral model for determining the transformational solvency index will consist of the sum of transformational solvency indices $\left(I_{i}^{s o l}\right)$, calculated using the $i$-th number of existing methods for determining the level of financial stability of the entity, and will be as follows (1):

$$
I_{t r}^{s o l}=\sum_{i=1} I_{i}^{s o l},
$$

where $I_{i}^{\text {sol }}$ is a transformational solvency index, calculated using the $i$-th existing method of determining the level of financial stability of the entity. This indicator can be determined by the following formula (2):

$$
\begin{aligned}
& I_{i}^{s o l}=I_{t_{0}}^{l i q}-I_{0}^{l i q}+\left(I_{t_{0}}^{l i q}-I_{t_{1}}^{l i q}+I_{t_{0}}^{l i q}-I_{t_{2}}^{l i q}+\right. \\
& \left.I_{t_{0}}^{l i q}-I_{t_{k}}^{l i q}\right) * k^{-1},
\end{aligned}
$$

where $I_{t_{0}}^{\text {liq }}$ is an indicator of current liquidity of the enterprise in the studied time period $t_{0}$;

$I_{0}^{l i q}$ is an indicator of the threshold value of the current liquidity of the enterprise, from which the risk of insolvency of the entity increases;

$I_{t_{1}, t_{2}, \ldots t_{k}}^{l i q}$ are liquidity indicators of the enterprise in time periods $t_{1}, t_{2}, t_{k}$, which precede the studied period $t_{0}$

$k$ is a quantitative expression of the set of time periods during which the study is carried out.

To provide a descriptive characteristic of the level of enterprise financial stability on the transformation index of solvency should use the following scale of definition:

$I_{t r}^{\text {sol }} \geq 40$ is an absolutely stable financial condition (all financial indicators of the enterprise are within normative values and have positive tendencies to growth);
$40<I_{t r}^{\text {sol }} \leq 20$ is a satisfactory stable financial condition (in the work of the enterprise there are certain financial difficulties, which are overcome in a timely manner due to operational controlling);

$20<I_{t r}^{s o l} \leq 0$ is a relatively stable financial condition (some financial indicators go beyond the normative values, the negative consequences of which the company overcomes using all available resources);

$0<I_{t r}^{\text {sol }} \leq-20$ is an unstable financial condition (most financial indicators go beyond the normative values, the company has the resources to overcome most of the negative consequences of this situation);

$-20<I_{t r}^{s o l} \leq-40$ is a critical financial condition (all financial indicators go beyond the normative values, the company has the resources to overcome most of the negative consequences of this situation);

$I_{t r}^{s o l} \geq-40$ is a bankruptcy (all financial indicators go beyond the normative values; the company has no resources to overcome the consequences of this situation).

Thus, the integral model of determining the transformation solvency index allows optimizing the procedure of controlling finances in the enterprise by simplifying the analysis of its economic activity based on obtaining a single determinant of financial stability by normalizing the set of financial ratios calculated by existing methods of assessing current financial condition. At the same time, it should be noted that it is important to determine the nature and strength of the factors influencing the formation of the transformational solvency index to develop measures to maintain the financial condition of the enterprise, overcome possible crises and prevent bankruptcy. These factors include the main indicators of accounting, reflected in the balance sheet of the enterprise (statement of financial position), namely: non-current assets $\left(F_{1}\right)$, current assets $\left(F_{2}\right)$, authorized capital $\left(F_{3}\right)$, retained earnings $\left(F_{4}\right)$, net profit $\left(F_{5}\right)$, current liabilities $\left(F_{6}\right)$. In turn, the nature and strength of the interaction of these factors with the value of the transformational solvency index can be determined by calculating the Bravais-Pearson correlation coefficient (3):

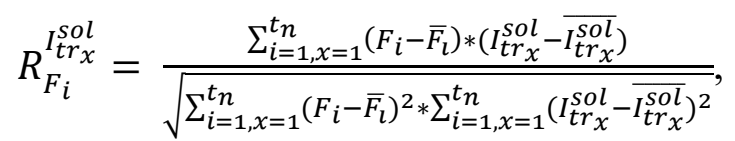

where $F_{i}$ is the value of the $i$-th factor influencing the transformation index of solvency of the studied enterprise $x$;

$\bar{F}_{l}$ is the average value of $F_{i}$ during a certain number of time periods $t_{n}$, for which the data is sampled;

$I_{t r_{x}}^{\text {sol }}$ is a transformational index of solvency of the enterprise $x$; 
$\overline{I_{t r_{x}}^{s o l}}$ is the average value of $I_{t r_{x}}^{s o l}$ for a certain number of time periods $t_{n}$, for which the data is sampled;

$t_{n}$ is the number of time periods $t_{n}$, for which the data is sampled.

It should be noted that the value of $R_{F_{i}}^{I_{t r_{x}}^{S o l}}$ can range from -1 to +1 . In this case, the closer the value of $R_{F_{i}}^{I_{\text {trr }}^{\text {sol }}}$ to -1 or +1 , the stronger the relationship between the transformational solvency index and a certain financial performance of the enterprise $\left(F_{1}, F_{2}, F_{3}, F_{4}, F_{5}, F_{6}\right)$, which affects it.

Approbation of the integral model for determining the transformation solvency index was carried out at five industrial enterprises of Luhansk region in Ukraine during 2016-2020, namely:

LLC "EKOTEKH", LLC "YALYNKOVI PRYKRASY", LLC "FERUM-STROI-SERVIS", PJSC "MYRNODOLYNSKYI DOSLIDNOEKSPEREMENTALNYI ZAVOD", LLC "VOVCHOIARIVSKYI KARIER".

The results of using this model to determine the nature and strength of the impact $\left(R_{F_{i}}^{I_{\text {trol }}^{\text {sol }}}\right)$ of financial performance of economic entities on the formation of the value of the transformational solvency index are shown in Table 1.

Table 1. Dynamics of change of transformation solvency indices of the enterprises and the factors causing their formation

\begin{tabular}{|c|c|c|c|c|c|c|}
\hline \multicolumn{7}{|c|}{ LLC “EKOTEKH” } \\
\hline \multicolumn{7}{|c|}{ Characteristics of financial condition - absolutely stable } \\
\hline \multirow{2}{*}{$I_{t r_{1}}^{s o l}$} & 2016 & 2017 & 2018 & 2019 & 2020 & \multirow{2}{*}{$R_{F_{i}}^{I_{t r_{1}}^{S o l}}$} \\
\hline & 45,2 & 44,2 & 63,6 & 40,2 & 79,2 & \\
\hline$F_{1}$ & 425,0 & 459,6 & 502,4 & 556,3 & 479,9 & 0,22 \\
\hline$F_{2}$ & 169,8 & 176,9 & 173,1 & 129,1 & 130,8 & 0,88 \\
\hline$F_{3}$ & 1344,9 & 1321,2 & 1281,2 & 1248,9 & 1217,4 & 0,71 \\
\hline$F_{4}$ & 482,6 & 617,5 & 812,0 & 822,5 & 687,8 & 0,36 \\
\hline$F_{5}$ & 18,2 & 27,3 & 30,4 & 44,2 & 59,2 & 0,77 \\
\hline$F_{6}$ & 18,6 & 31,8 & 30,2 & 48,9 & 25,3 & $-0,79$ \\
\hline \multicolumn{7}{|c|}{ LLC "YALYNKOVI PRYKRASY" } \\
\hline \multicolumn{7}{|c|}{ Characteristics of financial condition - critical } \\
\hline \multirow[t]{2}{*}{$I_{t r_{2}}^{\text {Sol }}$} & 2016 & 2017 & 2018 & 2019 & 2020 & \multirow{2}{*}{$R_{F_{i}}^{I_{t_{2}}^{\text {Sol }}}$} \\
\hline & $-20,9$ & $-25,9$ & $-24,1$ & $-29,8$ & $-30,9$ & \\
\hline$F_{1}$ & 479,4 & 207,9 & 123,9 & 87,6 & 479,4 & 0,31 \\
\hline$F_{2}$ & 171,8 & 180,9 & 105,1 & 91,1 & 88,8 & 0,93 \\
\hline$F_{3}$ & 561,8 & 455,7 & 452,3 & 432,1 & 422,1 & 0,61 \\
\hline$F_{4}$ & 290,6 & 482,6 & 617,5 & 812,0 & 822,5 & 0,28 \\
\hline$F_{5}$ & $-114,6$ & $-185,9$ & $-249,8$ & $-120,9$ & $-276,3$ & 0,66 \\
\hline$F_{6}$ & 366,6 & 366,9 & 42,1 & 30,1 & 154,0 & $-0,74$ \\
\hline \multicolumn{7}{|c|}{ LLC "FERUM-STROI-SERVIS" } \\
\hline \multicolumn{7}{|c|}{ Characteristics of financial condition - satisfactorily stable } \\
\hline \multirow[t]{2}{*}{$I_{t r_{3}}^{s o l}$} & 2016 & 2017 & 2018 & 2019 & 2020 & \multirow{2}{*}{$R_{F_{i}}^{I_{\text {trol }}^{S o l}}$} \\
\hline & 23,1 & 25,4 & 31,2 & 35,3 & 39,4 & \\
\hline$F_{1}$ & 1881,0 & 1950,3 & 1931,6 & 1884,3 & 1921,7 & 0,22 \\
\hline$F_{2}$ & 289,1 & 287,2 & 301,1 & 311,2 & 310,1 & 0,90 \\
\hline$F_{3}$ & 3472,1 & 3298,9 & 3148,2 & 2945,8 & 2730,2 & 0,70 \\
\hline$F_{4}$ & 249,6 & 261,8 & 286,0 & 435,6 & 942,7 & 0,32 \\
\hline
\end{tabular}

\begin{tabular}{|c|c|c|c|c|c|c|}
\hline$F_{5}$ & 15,2 & 14,2 & 19,0 & 12,1 & 9,8 & 0,69 \\
\hline$F_{6}$ & 263,2 & 250,8 & 237,6 & 226,6 & 14,3 & $-0,93$ \\
\hline \multicolumn{7}{|c|}{$\begin{array}{c}\text { PJSC "MYRNODOLYNSKYI DOSLIDNO- } \\
\text { EKSPEREMENTALNYI ZAVOD" }\end{array}$} \\
\hline \multicolumn{7}{|c|}{ Characteristics of financial condition - critical } \\
\hline \multirow{2}{*}{$I_{t r_{4}}^{S o l}$} & 2016 & 2017 & 2018 & 2019 & 2020 & \multirow{2}{*}{$R_{F_{i}}^{I_{t r}^{S o l}}$} \\
\hline & $-38,7$ & $-24,8$ & $-40,9$ & $-25,5$ & $-36,4$ & \\
\hline$F_{1}$ & 577,9 & 369,9 & 357,6 & 78,3 & 76,3 & 0,19 \\
\hline$F_{2}$ & 269,8 & 356,9 & 251,1 & 115,1 & 101,8 & 0,94 \\
\hline$F_{3}$ & 1000,5 & 901,1 & 885,4 & 784,2 & 654,1 & 0,71 \\
\hline$F_{4}$ & 189,2 & 200,2 & 172,1 & 177,9 & 181,2 & 0,27 \\
\hline$F_{5}$ & $-176,7$ & $-77,0$ & -154 & $-204,6$ & $-3,3$ & 0,78 \\
\hline$F_{6}$ & 201,2 & 100,3 & 101,2 & 90,1 & 85,4 & $-0,87$ \\
\hline \multicolumn{7}{|c|}{ LLC "VOVCHOIARIVSKYI KARIER" } \\
\hline \multicolumn{7}{|c|}{ Characteristics of financial condition - unstable } \\
\hline$I_{t r_{5}}^{S O l}$ & 2016 & 2017 & 2018 & 2019 & 2020 & \multirow{2}{*}{$R_{F_{i}}^{I_{t r l}^{S o l}}$} \\
\hline & $-11,1$ & $-13,8$ & $-15,2$ & $-6,4$ & $-7,7$ & \\
\hline$F_{1}$ & 22,2 & 37,9 & 37,4 & 23,3 & 26,5 & 0,24 \\
\hline$F_{2}$ & 12,4 & 23,3 & 21,8 & 9,0 & 11,9 & 0,96 \\
\hline$F_{3}$ & 193,0 & 193,8 & 104,5 & 82,6 & 91,2 & 0,61 \\
\hline$F_{4}$ & 235,6 & 180,9 & 240,7 & 389,2 & 292,4 & 0,31 \\
\hline$F_{5}$ & $-6,4$ & $-14,9$ & $-13,9$ & 22,4 & 0,0 & 0,73 \\
\hline$F_{6}$ & 51,6 & 82,3 & 95,8 & 59,3 & 62,6 & $-0,81$ \\
\hline
\end{tabular}

According to the data reflected in Table 1., it can be noted that during 2016-2020, only two of the surveyed enterprises have transformation indices of solvency, characterizing their financial condition as stable (LLC "EKOTEKH" $I_{t r_{1}}^{\text {Sol }} \geq 40$ and LLC "FERUM-STROI-SERVIS" $40<I_{t r_{3}}^{s o l} \leq 20$ ). The level of financial stability of other enterprises is at a fairly low level, which threatens the bankruptcy of PJSC "MYRNODOLYNSKYI EKSPEREMENTALNYI "VOVCHOIARIVSKYI KARIER", LLC "YALYNKOVI PRYKRASY" in the near future in the absence of appropriate actions to implement and optimize the system financial controlling and development on the basis of operative monitoring of the enterprise activity indicators of anti-crisis administrative measures. At the same time, it is worth noting that the correlation analysis of the nature and strength of the relationship between the transformation index of solvency and the selected financial indicators of economic activity showed a fairly strong direct relationship between the level of solvency and current assets, net profit, and equity. Thus, for the studied business entities, the correlation coefficient for current assets ranged from 0.88 to 0.96 , for net profit - from 0.66 to 0.78 , for equity from 0.61 to 0.71 . At the same time, the inverse relationship was observed between the transformation solvency index and short-term liabilities. The correlation coefficient for this indicator was in the numerical range $-0.74 \ldots-0.93$. The presence in the LLC "EKOTEKH" and LLC "FERUM-STROI-SERVIS" of positive trends in the dynamics of current assets, net profit, equity capital during 2016-2020, while maintaining a low level of liabilities, determined the stability of the financial condition of these business entities. However, in the 
PJSC "'MYRNODOLYNSKYI DOSLIDNOEKSPEREMENTALNYI ZAVOD", LLC "VOVCHOIARIVSKYI KARIER", LLC "YALYNKOVI PRYKRASY", the opposite situation is observed, characterized by a significant decrease in current assets and equity capital with a simultaneous increase in short-term liabilities, the timely repayment of which due to available financial resources is impossible in full.

Thus, the proposed integral model for determining the transformational solvency index allowed to assess the level of current financial stability of selected enterprises and to track trends in the dynamics of changes in the main factors that have a significant impact on the formation of this index. This model will be one of the indispensable components of the operational controlling system in financial management in the organization, providing managers with timely information in the amount necessary to make informed management decisions and identify appropriate measures to achieve the goals of enterprise development.

\section{Conclusion}

As a result of the research, there is an urgent need to implement and further improve the system of operational controlling in financial management in enterprises of any country in the world, including Ukraine. At the same time, one of the most important indicators that characterizes the efficiency of the enterprise and, accordingly, subject to control is its solvency, which determines the competitiveness and efficiency of adaptation of the business entity to adverse environmental conditions. In this regard, controlling based on the assessment of the level of financial stability plays a significant role in the optimal distribution and use of available financial resources in the operation of the enterprise.

To form a universal model for assessing the financial condition that would be suitable for use at any enterprises, regardless of the country of their operation, an integration model for determining the transformation index of solvency is proposed, in which all threshold values of the coefficients calculated according to the existing methods of assessing financial stability are reduced to one measurement scales; and the synergistic effect of the impact of financial indicators for several periods of economic activity is taken into account. That is, the proposed model optimizes the calculations of the solvency ratio based on obtaining a single determinant of the level of financial condition. In addition, the integral model of determining the transformational solvency index clearly demonstrates the degree of perfection or imperfection of economic development of the studied entity and provides operational monitoring of environmental factors on its financial condition, which, in turn, effectively formulate strategic goals of the enterprise and relevant measures to achieve them on the basis of prompt identification of risks of financial insolvency and early receipt of the necessary information for making sound management decisions.

\section{References}

[1]. Alharbi, I. B., Jamil, R., Mahmood, N. H. N., \& Shaharoun, A. M. (2019). Exploring the relationships between organizational culture, management control system and organizational innovation. Global Business Review, 0972150919870341.

[2]. Crespo, N. F., Rodrigues, R., Samagaio, A., \& Silva, G. M. (2019). The adoption of management control systems by start-ups: Internal factors and context as determinants. Journal of Business Research, 101, 875884.

[3]. Hnatenko, I., Orlova-Kurilova, O., Shtuler, I., Serzhanov, V., \& Rubezhanska, V. (2020). An approach to innovation potential evaluation as a means of enterprise management improving. International Journal of Supply and Operations Management, 7(1), 112-118.

[4]. Korhonen, T., Laine, T., \& Martinsuo, M. (2014). Management control of project portfolio uncertainty: A managerial role perspective. Project Management Journal, 45(1), 21-37.

[5]. Lunt, S. T. (1981). Management control systemsanalogies with process control systems as an aid to improved performance. Transactions of the Institute of Measurement and Control, 3(1), 3-12.

[6]. Martin, M. A. (2020). An evolutionary approach to management control systems research: A prescription for future research. Accounting, Organizations and Society, 86, 101186.

[7]. Pavlatos, O. (2021). Drivers of management control systems in tourism start-ups firms. International Journal of Hospitality Management, 92, 102746.

[8]. Samagaio, A., Crespo, N. F., \& Rodrigues, R. (2018). Management control systems in high-tech start-ups: An empirical investigation. Journal of Business Research, 89, 351-360.

[9]. Tou, Y., Watanabe, C., \& Neittaanmäki, P. (2020). Fusion of technology management and financing management-Amazon's transformative endeavor by orchestrating techno-financing systems. Technology in Society, 60, 101219.

[10]. Di Vaio, A., Varriale, L., \& Trujillo, L. (2019). Management Control Systems in port waste management: Evidence from Italy. Utilities Policy, 56, 127-135.

[11]. Wang, K. T., Wu, Y., \& Ho, K. Y. (2019). Internal control reporting and cost of bond financing: Evidence from China. International Review of Economics \& Finance.

[12]. Zos-Kior, M., Shkurupii, O., Hnatenko, I., Fedirets, O., Shulzhenko, I., \& Rubezhanska, V. (2021). Modeling of the Investment Program Formation Process of Ecological Management of the Agrarian Cluster. European Journal of Sustainable Development, 10(1), 571-571. 